\title{
A aproximação e a instalação dos aparatos de Controle do Poder Judiciário em Campo Mourão-PR
}

\author{
Approximation and installation of the apparatus of Control of the Judicial \\ Power in Campo Mourão-PR
}

\author{
Leandro Moreira da Luz ${ }^{1}$ \\ Bruno Flávio Lontra Fagundes ${ }^{2}$
}

\begin{abstract}
RESUMO
O artigo apresenta, a partir de análises e reflexões, os cenários e contextos regulatórios nos quais estão inseridos os atores sociais presentes nos primeiros processos crime de Campo Mourão, que datam entre os anos 1928 e 1949. Além dos acontecimentos constantes nestes autos, analisamos decisões regulamentares, leis, medidas administrativas e, também, literaturas acadêmicas referentes à ocupação do território neste período. O interesse em ler e analisar estas fontes se deu exatamente na expectativa de encontrar documentos que flagrassem os indivíduos sujeitos aos exames disciplinares pelos agentes do Poder Judiciário - homens e mulheres - agindo e descrevendo os sentidos de suas relações cotidianas em meio às políticas disciplinares e às possíveis tensões entre poderes e resistências.
\end{abstract}

Palavras-chave: História Moderna. Poder Judiciário. Controle. Disciplinação.

\section{ABSTRACT}

The article presents, from analyzes and reflections, the scenarios and regulatory contexts in which the social actors present in the first crime cases of Campo Mourão, that date between the years 1928 and 1949, are inserted. In addition to the events in these autos, we analyze regulatory decisions, laws, administrative measures and, also, academic literatures referring to the occupation of the territory in this period. The interest in reading and analyzing these sources was exactly in the expectation of finding documents that would expose individuals subject to disciplinary examinations by agents of the Judiciary - men and women - acting and describing the meanings of their daily relations in the midst of disciplinary policies and possible tensions between powers and resistances.

Keywords: Modern history. Judicial Power. Control. Discipline.

\footnotetext{
1 Mestre em Sociedade e Desenvolvimento, Universidade Estadual do Paraná. Unespar. E-mail: professorleandromoreira@gmail.com

2 Doutor em História, Universidade Estadual do Paraná. Unespar. E-mail: parabrunos@fecilcam.br
} 


\section{Prolegômenos}

Tendo em vista as múltiplas abordagens referentes às relações entre os sujeitos e as esferas institucionais na contemporaneidade, ${ }^{3}$ o presente estudo ${ }^{4}$ produz sua análise a partir de um instrumental e prisma foucaultiano ${ }^{5}$ das relações de poder e, também, a partir de outros textos e autores que nos oferecem categorias de análise fundamentais, tais como Pierre Bourdieu, Friedrich Nietzsche, Peter Burke etc. Tem como foco o processo paulatino de classificação/controle/regulação em um território que foi considerado inicialmente como uma "terra sem donos" e que posteriormente foi medido, demarcado, estabelecido e emancipado, tornando-se uma cidade dividida em funções e divisões do trabalho em razão do processo moderno de acumulação do capital.

Tomamos, também, a licença de nomear (ou, simplesmente, chamar de forma diferente do que está escrito na tradução do livro) algumas das ideias/conceitos dos autores supracitados para buscar uma melhor compreensão e apresentação do nosso texto. Chamamos de "disciplinação" o que, por vezes, a partir da tradução de Vigiar e Punir (1987), nos é apresentado como "adestramento". Consideramos que a disciplinação é o conjunto de técnicas, táticas, procedimentos, funcionamentos etc., utilizados pelas instituições disciplinares para tornarem os indivíduos úteis e dóceis, principalmente para o trabalho (o indivíduo é um efeito do poder disciplinador a partir dos dispositivos de disciplinação). A disciplina é, em primeiro lugar, um tipo de organização do espaço. Em segundo lugar, é um controle do tempo. Em terceiro lugar, tem na vigilância um de seus principais instrumentos de controle e, por fim, em último lugar, a disciplina implica num registro contínuo de

3 Entre os trabalhos que detêm estas abordagens citamos, como exemplo, os estudos de Chalhoub (2012) e Rago (2014).

4 Este artigo discute fundamentalmente a temática das relações de poder e controle presentes no processo de ocupação, urbanização e modernização de Campo Mourão-PR. Está vinculada ao Programa de Pós-Graduação em Sociedade e Desenvolvimento (PPGSeD) da Universidade Estadual do Paraná - Campus de Campo Mourão, ligada à linha de pesquisa Formação Humana, processos socioculturais e instituições. As discussões promovidas nesta linha objetivam, a partir de uma perspectiva interdisciplinar, indagar e compreender os processos socioculturais que se constituem nas relações dos sujeitos com as esferas institucionais tais como o Estado, a prisão, a escola, a cidade, a igreja etc.

5 Alvarez (2015) sinaliza que Michel Foucault por diversas vezes convidou seus ouvintes e leitores a tomarem suas ideias como hipóteses de trabalho, suas análises como experiências provisórias e seus livros como instrumentos/ferramentas para múltiplos usos possíveis. Numa de suas muitas citações sobre o pensador Nietzsche, o próprio Foucault diz: "o único sinal de reconhecimento para com um pensamento como o de Nietzsche é precisamente utilizá-lo, deformá-lo, fazê-lo ranger e gritar. Que os comentadores digam se é ou não fiel, isto não tem o menor interesse" [grifo nosso] (FOUCAULT, 2015, p. 233). Tal tipo de posicionamento nos fornece uma pista não apenas para compreender como Foucault se apropriava dos autores que se constituíam como efetivos instrumentos para o seu pensamento, mas também como desejava que o seu percurso intelectual fosse apropriado por outros pensadores. A metáfora do "instrumental" como trazemos no texto (ou como coloca Alvarez, da "caixa de ferramenta") se oporia desse modo "ao ritual acadêmico do comentário, que garantiria ao autor um lugar no conjunto da tradição filosófica, mas pagando o preço da neutralização das novas possibilidades abertas pelo seu pensamento, dos novos espaços de problematização que Foucault buscava obsessivamente desobstruir" (ALVAREZ, 2015, p. 16). 
conhecimento (FOUCAULT, 2015, p. 22-23). É a partir desta "disciplina" que se busca tornar os indivíduos "normais" ou "normalizados".

Nossa proximidade com o objeto de pesquisa, os atores sociais em processo de disciplinação, ou seja, os atores sociais que foram sujeitos aos exames disciplinares promovidos por instituições como a prisão, a escola, a igreja, a indústria, o quartel etc., durante o processo de urbanização e modernização da cidade de Campo Mourão entre 1928 e 1972, fomentou o interesse em pesquisar como se deu o desenvolvimento destes controles, classificações e regulações (e das relações de poder inerentes a estes), a partir da observação, análise, reflexões, contextualizações e comparações sobre a ação dos agentes sociais na busca pela normalização dos indivíduos através da utilização de toda uma engenharia disciplinar (e, às vezes, punitiva) organizada em disposições, manobras, táticas, técnicas e funcionamentos, desde as primeiras décadas do início da "construção/aparecimento" da futura cidade, continuadamente, até o momento em que podemos vislumbrar um espaço (locus) sendo organizado pelas instituições.

O recorte empírico deste artigo refere-se aos processos crime de Campo Mourão relativos ao período 1928-1949, dispostos em 18 processos, arquivados na Primeira Vara Criminal de Campo Mourão e codificados a partir de dois números: o primeiro que representa uma ordem crescente de entrada do processo no cartório da vara criminal e o segundo que representa o ano de arquivamento deste processo:

Caixa 1 (18 processos): Autos 2/49, 4/49, 3/49, 13/49, 05/49, 09/49, 11/47, 14/49, $12 / 49,6 / 49,7 / 49,10 / 49,16 / 49,17 / 49,19 / 49,20 / 49,18 / 49$ e 8/49;

Portanto, apresentamos, a partir de análises e reflexões, os cenários e contextos regulatórios nos quais estão inseridos os diversos atores sociais presentes nos primeiros processos crime de Campo Mourão, que datam entre os anos 1928 e 1949. Encontramos um locus em via de apropriação legal pelos atores sociais, ou seja, um local onde se começa a estabelecer "propriedades legalizadas" no lugar de "posses por tradição", com a aproximação e instalação dos aparatos de controle judiciário, num contexto tenso de normalização destes atores (o sujeito "normal" é aquele que internaliza seu papel de dócil e de útil numa lógica de acumulação de bens e aceitação do poder de decisão de alguns no movimento de normalização social).

\section{O Caminho Científico}

Trataremos aqui dos aspectos teóricos e práticos da nossa pesquisa, considerando a metodologia, os protocolos, a coleta e análise dos dados e o relatório. Em linhas gerais, trata- 
se de uma pesquisa exploratória. Nosso objeto de pesquisa são os atores sociais em processo de disciplinação durante o decurso de urbanização e modernização da cidade. Analisamos a sociedade buscando demonstrar o quanto as estratégias de disciplinação passam pelo funcionamento da engenharia disciplinar do Poder Judiciário. A coleta dos dados se deu a partir de análises prospectivas, quantitativas e qualitativas, sob fontes primárias e secundárias: processos crime, decisões regulamentares, leis, medidas administrativas, enunciados científicos, proposições filosóficas, morais, filantrópicas, os textos dos historiadores memorialistas de Campo Mourão, as fotos colecionadas no Museu Municipal, vídeos publicitários sobre a cidade etc. Em suma, apresentamos os meandros e estratégias de pesquisa que nos levaram a conhecer o processo inicial regulatório de urbanização e modernização da cidade.

Em meio ao desafio subjetividade/objetividade (ser subjetivo e objetivo ao mesmo tempo) e às motivações e interesses do meio acadêmico, escolhemos nosso objeto de pesquisa: os atores sociais em processo de disciplinação no decorrer da urbanização e modernização da cidade de Campo Mourão.

Uma característica marcante da pesquisa científica nas chamadas Ciências Humanas e Sociais é a investigação de questões que ainda não foram totalmente solvidas pela sociedade e que estão abertas para discussões e debates no meio acadêmico, questões que abrangem temas pelos quais os agentes das instituições acadêmicas detêm interesses e motivações. Chamamos estas questões, comumente, de "problemas de pesquisa". Estes problemas de pesquisa apresentam-se em forma de suspeitas e dúvidas que, de antemão, no caminho/guia/lead da persecução científica, sugerem prováveis respostas - as hipóteses de pesquisa (GIL, 1991).

Estas hipóteses, ou esta impressão de já possuirmos, a priori, uma "resposta" ou um "melhor caminho" à solução dos problemas de pesquisa, devido, provavelmente, às nossas leituras, estudos, formação, convivências, repertórios ou mesmo imposições externas etc., é algo, em geral, inevitável. Por isso, na busca de respostas contundentes e indispensáveis aos nossos problemas de pesquisa consideramos, de início, a "subjetividade" (o "eu"), os interesses do meio acadêmico em que estamos inseridos e as propriedades do nosso "objeto de pesquisa".

No início, teoricamente, entendemos que nosso objeto é um objeto híbrido ou um "quase objeto".

Para Latour (1994, p. 64) os híbridos ou "quase objetos" são aqueles que "não pertencem a natureza, nem a sociedade nem ao sujeito, e também não pertencem a linguagem [...]" (pertencem a todos), inserindo-se num complexo por produzir um emaranhado 
de ações, interações e retroações. É fundamental frisar que entre os demais parâmetros para a construção do planejamento e desenho de pesquisa, no objetivo de obter maior e melhor rigor e coerência, visão do tipo de dados, visão abrangente das alternativas de olhar permitindo adaptação e superação da rigidez/padronização é de suma importância considerar as características do objeto (VASCONCELOS, 2007).

Percebemos necessário a esta pesquisa, então, a construção contínua de um planejamento com estratégia.

Para Edgar Morin (1996, p. 284), a estratégia é a arte de trabalhar com a incerteza: "é necessário estabelecer uma diferença entre cronograma e estratégia: penso que ali está a diferença entre o pensamento simplificante e o pensamento complexo". Patrick Paul (2011), neste mesmo diapasão, sentencia "[...] todo pensamento complexo é paradoxal [...] como consequência, o conhecimento assume novas feições, que se chamam dialética (ou dialógica), hibridez, não linearidade, reflexividade, heterogeneidade, multirreferencialidade [...]", o que demanda uma mudança de olhar, ou de vários olhares num sentido de cooperação entre as áreas do saber buscando uma análise por meio de um novo paradigma: o paradigma interdisciplinar: "[...] o novo paradigma desenvolve nova organização das relações. Ele concebe um progresso epistemológico e metodológico, dados múltiplos, eventualmente contraditórios, complexos e paradoxais [...]" (PAUL, 2011, p. 236, 257).

Uma abordagem integrada, a criação de condições de diálogo, cooperação, o cruzamento de olhares entre disciplinas como, por exemplo, a História, a Geografia, o Direito, a Sociologia, a Economia, entre outras, e a busca por um olhar crítico e reflexivo sobre a produção do conhecimento foram essenciais para o favorecimento da cooperação entre os domínios do saber presentes em nossa pesquisa frente à complexidade e o caráter híbrido do nosso objeto. Neste ínterim, Claude Raynaut (2014, p. 15) recomenda que, para otimizar a busca por resultados satisfatórios na pesquisa científica sob uma perspectiva interdisciplinar, é necessário,

\footnotetext{
i. Abrir as mentes e baixar as barreiras intelectuais;

ii. Favorecer uma convergência de olhares;

iii. Proporcionar a aprendizagem de prática e instrumentos concretos.
}

Considerando o caráter híbrido do objeto, o "pensamento complexo", a necessidade de cooperação entre áreas do saber e as recomendações supracitadas, iniciamos nossa pesquisa a partir de uma análise prospectiva: uma visão sistemática visando orientar nossa ação presente à luz dos possíveis planejamentos futuros (GODET, 1985).

Ao adentrarmos no arquivo da Primeira Vara Criminal de Campo Mourão, diante da impossibilidade de realizar um estudo sobre todos os processos ali arquivados, escolhemos a 
caixa de arquivo considerando sua ordem cronológica. Esta caixa possui processos com datas entre 1928 e 1949 (feitos instaurados no momento de aproximação e instalação dos aparatos de controle judiciário na cidade).

Diante da necessidade de constituir um recorte temporal, escolhemos a possibilidade metodológica de fechamento amostral por saturação teórica das informações. Nesta toada, citamos as palavras de Fontanella, Ricas e Turato (2008, p. 17):

\begin{abstract}
O fechamento amostral por saturação teórica é operacionalmente definido pela suspensão de inclusão de novos personagens quando os dados obtidos passam a apresentar, na avaliação do pesquisador, certa redundância ou repetição, não sendo considerado persistir na coleta de dados. Noutras palavras, as informações fornecidas pelos novos participantes da pesquisa pouco acrescentariam ao material já obtido, não mais contribuindo para o aperfeiçoamento da reflexão teórica fundamentada nos dados que estão sendo coletados.
\end{abstract}

O recorte e o ajuste foram acontecendo enquanto aproximávamos do nosso objeto e, considerando o objetivo inicial de demonstrar o continuum disciplinar aplicado sobre o locus em análise ${ }^{6}$ limitamos nossa análise a partir da saturação (fechamento) das informações coletadas, ajustando nosso recorte temporal para os anos de 1928-1949.

$\mathrm{Na}$ análise do campo documentário observamos os eventos que se repetem sistematicamente: "versões que se reproduzem muitas vezes, aspectos que ficam mal escondidos, mentiras ou contradições que aparecem com frequência" (CHALHOUB, 2012, p. 41), além de outros pontos nos autos que consideramos importantes como, por exemplo, dados dispersos ou encobertos.

Após a primeira aproximação aos processos-crime: conhecimento, afolhamento, registros em nosso diário de pesquisa, coleta de dados etc., empreendemos uma análise quantitativa. Esperávamos que os dados quantitativos e suas possíveis proxies ou medidas aproximadas e indiretas poderiam contribuir para captar determinados fenômenos como, por exemplo, os procedimentos e funcionamentos das estratégias disciplinares impostas pelos agentes do Judiciário. Nas palavras de Ramos (2013, p. 59, 65):

[...] questões que envolvem relações causais, por meio das quais testamos hipóteses, pressupõem o uso de métodos quantitativos de forma que possamos verificar se determinadas variáveis (independentes ou dependentes) andam juntas e qual o sentido e a força da relação entre elas: se unidirecional ou recíproco e se é obra do acaso ou possui significância estatística [...] Se acreditarmos que existe uma realidade a ser descoberta (mesmo se essa realidade nunca seja totalmente distinta de nossas teorias), qualquer método que forneça informações novas sobre essa realidade é bem vindo, e tanto métodos quantitativos como métodos qualitativos podem contribuir para nosso conhecimento empírico do mundo social.

6 Este espaço, ao qual, no decorrer do texto, chamaremos de locus, refere-se ao "território de Campo Mourão". Não se trata de um espaço imutável/fixo, pois durante o período/recorte cronológico de análise houve mudanças significativas em relação à sua extensão geográfica, as classificações do espaço, à densidade demográfica, entre outros fatores. 
Portanto, consideramos de suma relevância a organização dos dados quantitativos para uma melhor aproximação e análise dos processos-crime. Neste sentido, podemos dizer que a análise quantitativa:

a) Partiu da necessidade de organizar os dados para:

i. Analisar a principal fonte de pesquisa (processos criminais) no sentido de identificar cenários, contextos e perfis dos atores;

ii. Criar planilhas, tabular e analisar as principais relações/inferências sobre os dados;

iii. Utilizar proxies ou medidas aproximadas e indiretas para relacionar cenários, contextos e atores.

iv. Planejar os próximos "passos" da pesquisa.

b) Busca a objetividade em meio às regularidades, influências, contradições, paradoxos, incertezas, hibridez, heterogeneidades, multirreferencialidades, subjetividades etc.

A partir dos dados quantitativos (idade, profissão, residência, filiação, religião, escolaridade etc.) presentes nos autos, podemos notar, por exemplo, a aproximação dos aparatos de controle judiciário sobre a cidade; a existência da divisão hierárquica entre os personagens dos autos; o detalhamento cada vez mais minucioso nas classificações dos indivíduos etc., notamos os sujeitos em processo de disciplinação no processo de urbanização de Campo Mourão, dentro de uma estrutura judiciária onde os atores sociais que se revestem do poder estatal atuam como "agente forte" ajudando a criar/fabricar "pessoas disciplinadas".

Observamos que os autos, normalmente, estão em um único bloco que enfeixam uma série de documentos - da petição inicial (libelo acusatório) até a sentença. Para Luiz Antônio Francisco de Souza (1998, p. 25), deve-se tomar a estrutura interna dos processos crime tal qual a encontra ao manusear os documentos, "tomá-los exatamente como processos, uma tentativa não acabada de construção da verdade ou, ao menos, da verossimilhança, em torno de um caso de quebra de leis penais e normas sociais". Entendemos que os documentos analisados são elaborados a partir de estreitos limites que se interpõem entre a "realidade", a fórmula judiciária e a autoria do texto.

Em seu estudo sobre o uso de documentos judiciais e policiais como fonte de pesquisa, Souza em conjunto com Rosemberg (2009, p. 168) relata, também, que é fundamental compreender o sistema em que os documentos estão dispostos nos autos, muitas vezes incompletos e fragmentados, como um feixe de documentos autônomos e, muitas vezes independentes: 
No processo-crime, existe uma pluralidade de vozes que se cruzam, se esbarram e se complementam num mesmo processo. Acondicionadas na justeza dos discursos, as falas são expressas de maneira díspar. Não se pode atribuir o mesmo estatuto a uma sentença, a um bilhete anônimo juntado nos autos, a um recorte de jornal, a um depoimento de um analfabeto, ao inquérito do delegado (e, portanto, de origem policial), ao parecer do promotor (de origem judiciária). Claro que a manipulação por parte dos responsáveis pela confecção dos autos deturpa e limita os discursos, mas o processo crime não pode ser encarado como uma peça monolítica. Assim, cada um dos elementos deve ser abordado com um cuidado singular e essencial.

Carlos Antônio Costa Ribeiro (1995, p. 24), dando voz a Pierre Bourdieu, ensina que devemos levar em consideração que há vários agentes presentes na produção dos autos,

[...] a formalização dos atos reais nos autos do processo passa pela retradução de todos os elementos do 'caso' para construir o 'objeto' de controvérsia enquanto 'causa', ou seja, um caso ou um ato devem ser traduzidos em autos para tornarem-se um problema jurídico que possa ser discutido, debatido e julgado nos tribunais. $\mathrm{Na}$ atividade de transformação, ou formalização, dos atos em autos estão presentes os diversos funcionários do sistema jurídico-policial.

Boris Fausto (1984, p. 32-33) relata que a verdade dos autos não seria neutra, mas uma produção do discurso numa batalha pela validação de uma versão:

\begin{abstract}
O processo se corporifica por meio de uma série de procedimentos, dentre os quais se destaca um conjunto de falas de personagens diversos. A emissão dessas falas e forma de captá-las não é diferente da construção do processo. Tomemos o caso das testemunhas e do acusado. Se é certo que qualquer discurso desfigura mecanismos e conteúdos internalizados, ainda quando se procura torná-lo mais livre possível, isso é tanto mais verdadeiro no caso específico, onde a intenção é imposta. As condições em que se produz a fala das testemunhas dificultam a emissão; o objetivo dos que aparentemente a liberam conduzem, pelo contrário, à sua ruptura.
\end{abstract}

A disposição dos documentos, suas possíveis autonomia e independência em relação ao processo e a presença de vários agentes interessados na construção destes documentos são alguns dos pontos fundamentais que levamos em consideração em nossa pesquisa.

Num segundo momento da pesquisa, e em conjunto com a análise quantitativa, começamos as leituras e estudos dos textos discursivos presentes nos autos.

Consideramos a ação/omissão dos agentes operadores do Direito e dos sujeitados ao exame (manobras), a codificação incriminadora (disposições), os exames (procedimentos), os protocolos estabelecidos (funcionamentos) e a forma de combinação destes fatores (táticas e técnicas - tecnologia) como estratégias e efeitos de controle na produção das subjetividades a partir das práticas judiciárias (FOUCAULT, 1987, p. 29). Observando estes fatores, fazemos nossa análise sobre como se dá a disciplinação dos atores sociais a partir dessa série de mecanismos estratégicos de controle.

Paralelamente à observação e seleção dos processos e coleta, tabulação e análise dos dados quantitativos foram realizados estudos bibliográficos e conceituais acerca dos escritos de Michel Foucault, Pierre Bourdieu, Friedrich Nietzsche, Peter Burke etc., e sobre os diversos textos que dialogam com estes (Sidney Chaloub, Margareth Rago, Oswaldo Giacoia Junior, 
Judith Revel, Salma Tannus Muchail, Paul Veyne etc.). Realizamos um estudo acerca das temáticas relacionadas aos micropoderes, resistências, controle, o poder-saber, sociedade disciplinar, panóptico, dispositivo, instituições, campo social entre outros. Com este estudo e exame dos conceitos históricos, sociológicos, jurídicos, filosóficos etc., acreditamos dar início à busca de evidências contextuais e históricas expostas nos processos crime.

Analisamos em conjunto com os textos supracitados, decisões regulamentares, leis, medidas administrativas, enunciados científicos, proposições filosóficas, morais, filantrópicas, os textos dos historiadores memorialistas de Campo Mourão, fotos colecionadas no museu municipal, vídeos publicitários sobre a cidade etc., comparando, identificando e contrastando os dados descritivos e valorativos através dos discursos apresentados pelos atores sociais. De acordo com Richardson (1999, p. 23): "descrever a complexidade de determinado problema, analisar a interação de certas variáveis, compreender e classificar processos dinâmicos vividos por grupos sociais" são focos dos procedimentos qualitativos.

A partir desta aproximação com as fontes de pesquisa, na busca de relacionar cenários, contextos e atores em possíveis regularidades, influências, contradições, paradoxos, multirreferencialidades etc., procuramos, buscando a objetividade, compreender (verstehen) o fenômeno estudado.

\begin{abstract}
Se o conhecimento causal do historiador consiste na imputação de certos resultados concretos e determinadas causas concretas, então é impossível uma imputação válida de qualquer resultado individual sem a utilização de um conhecimento nomológico, isto é, de um conhecimento das regularidades das conexões causais. Para saber se cabe atribuir um a um elemento individual e singular de uma conexão, na realidade, uma importância causal para o resultado que se trata de explicar casualmente, só existe a possibilidade de proceder a avaliação das influências que nos habituamos a esperar geralmente, tanto deste como de outros elementos do mesmo complexo, que sejam pertinentes à explicação. Essas influências constituem, por conseguinte, os efeitos "adequados" dos elementos causais em questão (WEBER, 2006, p. 129).
\end{abstract}

$\mathrm{Na}$ verstehen como um princípio epistemológico, a pesquisa qualitativa tenta entender o fenômeno ou evento em estudo desde dentro (FLICK, 2007). O que deve ser entendido é a visão de um sujeito ou de diferentes assuntos, o curso das situações sociais (conversas, discurso, processos de trabalho) ou as regras culturais ou sociais pertinentes a uma situação. Como esse conhecimento é expresso em termos metodológicos depende da posição teórica que sirva de base para a pesquisa.

Quanto à análise discursiva, fez-se necessário uma busca insistente do sentido último ou oculto das coisas, isto é, um "ir além" de uma possível ideia preestabelecida da existência de significantes com significados "neutros", pois, para Foucault, o "signo/símbolo" carrega um "significado, quase sempre oculto, dissimulado, distorcido, intencionalmente deturpado, cheio 
de 'reais' intenções, conteúdos e representações, escondidos nos e pelos textos, não imediatamente visíveis" (FISCHER, 2012, p. 198). Nas palavras de Foucault (1986, p. 56):

\begin{abstract}
[...] gostaria de mostrar que o discurso não é uma estreita superfície de contato, ou de confronto, entre uma realidade e uma língua, o intrincamento entre um léxico e uma experiência; gostaria de mostrar, por meio de exemplos precisos, que, analisando os próprios discursos, vemos se desfazerem laços aparentemente tão fortes entre as palavras e as coisas, e destacar-se um conjunto de regras, próprias da didática discursiva [...] não mais tratar os discursos como um conjunto de signos (elementos significantes que remetem a conteúdos ou a representações), mas como práticas que forma sistematicamente os objetos que falam. Certamente os discursos são feitos de signos; mas o que fazem é mais que utilizar os signos para designar coisas. É esse mais que os torna irredutíveis à língua e ao ato da fala. É esse "mais" que é preciso fazer aparecer e que é preciso descrever [grifo nosso].
\end{abstract}

É fundamental analisar a práxis, pois as palavras e as coisas estão imersas em relações de saber e poder, uma na outra, em enunciados e visibilidades, instituições e textos. Nas palavras de Blikstein (1995, p. 58) "a percepção e a linguagem é que estariam indissoluvelmente ligadas à práxis social, que é indefectível e vital para a existência de qualquer comunidade" e, também, para ordem dos discursos, reciprocamente. Para tanto, adotamos como metodologia a observação de indícios e pormenores, que estão presentes nos documentos e que podem nos demonstrar pressupostos e preconceitos constantes nos pensamentos da época. Deste universo, quanto à análise das relações de poder, selecionamos as fontes que melhor demonstraram em seus textos o conjunto de enunciados que dão condições de possibilidades na definição dos discursos dos personagens (MACHADO, 1974).

Por fim, trocando em miúdos, apresentamos alguns homens e mulheres atuando em seu cotidiano, buscando dar sentidos às existências, agindo ou resistindo à ação de outrem, fazendo parte fundamental num processo que ordenadamente e/ou desordenadamente, propositalmente ou não, transformou, de maneira substantiva, as características originais do local onde estes atores sociais "escolheram" atuar.

\title{
Cenário e Contexto Regulatórios entre 1928-1949 em Campo Mourão-PR
}

Em 1916, com a Lei $n^{\circ} 1559$ de 29 de março em seus artigos $1^{\circ}$ e $2^{\circ}$, houve a positivação ${ }^{7}$ da incorporação ao patrimônio da Câmara Municipal de Guarapuava-PR dos lugares denominados "Serra de Pitanga" e "Campo do Mourão":8

7 Falar em positivação significa falar de um enunciado prescritivo válido num determinado ordenamento jurídico vertido numa linguagem prescritiva, que disciplina o comportamento humano em suas relações intersubjetivas. Este fenômeno jurídico 
Art. $1^{\circ}$ - Fica concedida à Câmara municipal de Guarapuava a área de dois mil hectares de terras devolutas, na Serra de Pitanga e igual área no Campo do Mourão do mesmo município, destinadas a constituir as respectivas futuras povoações.

Art. $2^{\circ}$ - Estas terras serão incorporadas ao Patrimônio da referida municipalidade, que as mandará medir e demarcar para cedê-las em lotes como for mais conveniente [grifo nosso]. ${ }^{9}$

Notamos, neste ato de positivação, um dos esforços iniciais para o controle do local com expectativas de constituir futuras povoações no processo de ocupação promovido pelos agentes do Estado.

Silva (2008), em seus estudos, disserta que os interesses e/ou necessidades de construir um arranjo racional para os territórios que nunca foram de propriedade de um particular, mesmo estando ocupados, se confluem com o aparente intuito de organizar um modelo de gestão que estabelecesse controle dos indivíduos e lugares frente a crescente expansão e isolamento das famílias.

O fato deste patrimônio ser inicialmente considerado como "terra devoluta" sinaliza outras evidências sobre suas características. Di Pietro (2003, p. 587) descreve terras devolutas dizendo que "são assim consideradas aquelas que não estão destinadas a qualquer uso público nem incorporadas ao domínio privado". Etimologicamente, do latim devolutus, o termo significa desocupado, desabitado. "Tomou este sentido porque originalmente o latim devolutus é particípio de devolvere: voltar, rolar de cima. Designa terras que ainda não foram incorporadas à propriedade privada e, portanto, pertencentes ao Estado" (SILVA, 2014). Ou seja, as terras devolutas são consideradas terras públicas que em nenhum momento integraram o patrimônio de um particular, ainda que estejam sob sua posse.

O Instituto de Terras, Cartografias e Geociências (ITGC), dentro da legislação de terras, apresenta os seguintes critérios de conceituação para "terras devolutas":

Sua conceituação, como é tradição da legislação de terras, obtêm-se pelo método da exclusão: devolutas são as terras que foram incorporadas ao patrimônio do Estado nos termos do artigo 64 da Constituição Federal de $1891^{10}$ e não passaram pelo domínio particular por força da Lei Imperial de Terras (Lei $n^{\circ} 601$, cit.) e seu Regulamento (Decreto $n^{\circ} 1.318$, de 30 de janeiro de 1854), da Lei Estadual de 1892, em virtude da alienação, concessão, reconhecimento por parte do Estado, sentença judicial com força de coisa julgada (TERRAS E CIDADANIA, 2008, p. 17).

transforma-se numa produção de decisões que criam normas escritas (positivadas). Em outras palavras, podemos afirmar que há um esforço social para que uma norma hipotética transforme-se de uma praxis em uma poiesis ou vice-versa (FERRAS JÚNIOR, 2003).

8 De acordo com Veiga (1999, p. 33), este ato administrativo gerou um custo pecuniário ao município: "por essa aquisição a Câmara municipal pagou ao Estado cento e dezessete mil réis".

9 CAMPO Mourão. Folha de Londrina, Londrina, 10 out. 1976. Edição especial.

10 Constituição da República de 24 de fevereiro de 1891:

"Art. 64 - Pertencem aos Estados as minas e terras devolutas situadas nos seus respectivos territórios, cabendo a União somente a porção de território para defesa das fronteiras, fortificações, construções militares e estradas de ferro federais".

"§ Único - Os próprios nacionais, que não forem necessários para serviços da União passarão ao domínio dos Estados, em cujo território estiverem situados". 
Portanto, estes dois mil hectares referentes ao "Campo do Mourão", considerado a partir de 1916 como um patrimônio do município de Guarapuava, não tinham passado pelo domínio particular em virtude de alienação ou concessão de forma reconhecida pelo Estado.

Concomitantemente a incorporação destes dois mil hectares de terras devolutas à Câmara Municipal de Guarapuava houve nova categorização do patrimônio/vila de Campo do Mourão para "distrito policial" e, cinco anos após, em 1920, para "distrito judiciário". Estas categorizações nos sinalizam que os agentes deste espaço territorial passaram a ter competência para fiscalizar, instaurar e coordenar inquéritos policiais (TOURINO FILHO, 2005). ${ }^{11}$ Ou seja, indicam uma aproximação de aparatos policiais com a provável intenção de prevenir o desenvolvimento de uma possível criminalidade.

Em meio a estas classificações e categorizações, em 19 de setembro de 1925 Guarapuava passou a ter o domínio pleno sobre este distrito, incorporando este patrimônio ao seu município, evento este positivado com o título de $n^{\circ} 000013$ (VEIGA, 1999). A política estratégica de controle do espaço, confirmada pela Lei $\mathrm{n}^{\circ} 1559$ de 29 de março de 1916 e pelo título de $n^{\circ} 000013$ de 19 de setembro de 1925 demonstram as ações de controle deste espaço. Nos escritos de Veiga (1999, p. 93-94), a gestão do espaço, a partir de medições de demarcações, se efetivaram da seguinte forma:

\footnotetext{
Ao norte: Pelo rio Quilômetro 123, confronta com a gleba nำ da colônia Mourão, e terras devolutas do Estado por uma linha reta e seca na extensão de 6.009,00m., que, do Marco XXIII vai até o Marco XXXVIII, à margem esquerda do rio do Campo.

Ao Sul: Pelo rio Quilômetro 119 e uma linha reta e seca na extensão de 2.307,50m., que, do Marco IV vai ao Marco IX, confronta com terras tituladas a Miguel Luiz Pereira, e terras devolutas do Estado, por uma linha reta e seca na extensão de 1.622,60m., e pelo rio do Campo.

A leste: Pelo rio do Campo, confronta com terras devolutas do Estado.

A sudoeste: Por uma linha reta e seca na extensão de $1.136,30 \mathrm{~m}$., confronta com terras tituladas a Luiz Losso e Domingos Mendes e Irmãos.

A oeste: Por uma linha reta e seca na extensão de $2.835,00 \mathrm{~m}$., confronta com terras devolutas do Estado.
}

Os estudos de Silva (2008, p. 31) nos mostram que "os primeiros quarteirões foram demarcados no divisor dos rios Quilômetro 123 e do Campo, no qual se situam hoje a Praça Getúlio Vargas, a antiga Estação Rodoviária Municipal e o Instituto Santa Cruz" (uma escola), no centro da cidade.

O local destinado à Praça Getúlio Vargas ficava próximo ao Bosque das Copaíbas e das residências da família Albuquerque, conforme informações colecionadas no Museu Municipal Deolindo Mendes Pereira. 
Figura 1 - Local destinado à Praça Getúlio Vargas em 1940

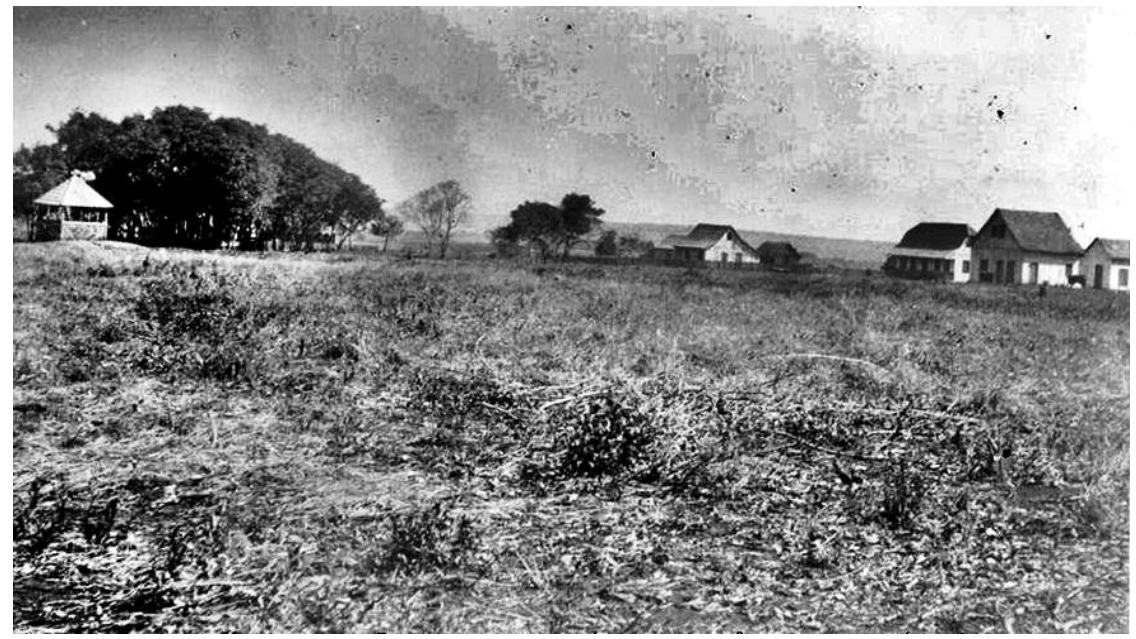

Fonte: Acervo do Museu Deolindo Mendes Pereira

Entendemos que a ação de medição, demarcação e o estabelecimento dos primeiros quarteirões para o lugar da praça, a estação rodoviária e a escola (próximo a determinadas residências) se fez de forma politicamente estratégica. São espaços que se relacionariam com todos os outros sítios, ou seja, que se encadeiam uns nos outros. A alocação destes lugares definiria as relações de vizinhança entre todos os outros pontos ou elementos (FOUCAULT, 2001). Ou seja, a escolha do lugar para a praça central deu marco de referência e estabelecimento de outros lugares na cidade.

Esta maneira de organização muito se aproxima da forma citada por Michel Foucault em seus escritos, quanto à disposição de algumas aldeias fundadas na América do Sul:

\begin{abstract}
A própria aldeia era fundada segundo um plano rigoroso: a matriz seria um lugar retangular, na base do qual estaria a igreja; de um dos lados, a escola, do outro, o cemitério; à frente da igreja uma longa avenida que seria cortada por uma outra, transversal; e cada família teria a sua cabana ao longo destes dois eixos. Assim estava reproduzido o símbolo de Cristo, em toda a sua acuidade. A Cristandade delimitava o espaço e a geografia do mundo americano pelo seu símbolo fundamental (FOUCAULT, 2001, p. 7).
\end{abstract}

Temos no estabelecimento dos primeiros quarteirões da futura cidade, a alocação de sítios que representam uma sociedade numa forma aperfeiçoada ou numa forma ainda planejada (utópica).

Por fim, observamos um locus em fase inicial de alocação dos lugares, evento sinalizado pela positivação dos comandos de medição e demarcação e estabelecimento dos lugares (disposições normativas). Trata-se de um território considerado como terras devolutas em 1916 que, posteriormente, foi categorizado, também, como vila/território e distrito 
policial/judicial (1920) ganhando competência para vigiar e controlar as manifestações sociais e/ou resistências ao controle que eram consideradas inadmissíveis.

\section{A Aproximação dos Aparatos do Poder Judiciário}

No arquivo da Primeira Vara Criminal, na caixa de $n^{\circ} 01$ onde estão guardados os primeiros autos referentes aos feitos delituosos do território que viria a ser posteriormente a cidade, encontramos três processos-crime relativos ao distrito judiciário de Campo Mourão que, nesta época (1928-1939), estava subordinado à comarca de Guarapuava:

Tabela 1 - Processos sob a jurisdição da comarca de Guarapuava (1928 - 1939) ${ }^{12}$

\begin{tabular}{ccccc} 
Comarca & Data & Local & Crime & Autos \\
\hline Guarapuava & $08 / 11 / 1928$ & Chupador & Homicídio culposo & $2 / 49$ \\
\hline Guarapuava & $26 / 07 / 1939$ & Campo Mourão & Lesões corporais & $3 / 49$ \\
\hline Guarapuava & $26 / 07 / 1939$ & Campo Mourão & Lesões corporais & $4 / 49$ \\
\hline
\end{tabular}

Fonte: Arquivo da Primeira Vara Criminal de Campo Mourão-PR

Conforme os dados acima, no período entre 1928 e 1939, três feitos criminais foram alcançados pelos aparatos jurídicos do distrito judicial de Campo Mourão, os delitos nestes autos foram caracterizados como homicídio culposo e lesões corporais nos termos da Consolidação das Leis Penais que codificava as práticas ilícitas no país. No que concerne à tipificação destes delitos é citada nos autos a Consolidação de Vicente Piragibe de 1932 que foi aprovada e adotada conforme o decreto $n^{\circ} 22.213$, de 14 de Dezembro de 1932 como "Consolidação das Leis Penais" que, por sua vez, previa as seguintes punições àqueles que infringissem suas normativas: a) prisão cellular; b) banimento; c) reclusão; d) prisão com trabalho obrigatório; e) prisão disciplinar; f) interdicção; g) suspensão e perda do emprego público, com ou sem inabilitação para exercer outro; h) multa (Artigo 43).

Nos autos 2/49 onde, de acordo com a denúncia, Ignácio e João estavam roçando e brincando com o revólver de João quando, por acidente, Ignácio deu-lhe um tiro no peito, matando-o. A tipificação deste ilícito, fator preponderante para sujeitar Ignácio à vigilância dos agentes do Poder Judiciário, foi feita a partir do que dispõe o Art. 294 da Consolidação das Leis Penais. Nos autos 3/49 onde, após ter mantido rápidas trocas de palavras com os irmãos Euclides e Francisco, a vítima Valencio recebeu diversos golpes de "mango e relho", é citado, inicialmente, o Art. 24 do regulamento que baixou o Decreto Federal n 1.441 de 08/08/1937. Ambas as condutas citadas são codificadas a partir de uma engenharia disciplinar presente 
numa codificação nacional de processo penal vigente anteriormente ao Decreto-Lei $n^{\circ} 3.689$, de 3 de Outubro de 1941 (Código de Processo Penal). Esta engenharia é sem dúvida um dos instrumentos fundamentais na economia do controle dos sujeitos por parte dos agentes do Estado (a norma como referência). ${ }^{13}$

Entendemos a forma de apresentação destas codificações supracitadas (artigos, incisos, parágrafos etc.), também, como uma das técnicas de poder utilizadas pelos agentes do Judiciário nas ações disciplinadoras dos sujeitos (tornaram-se sujeitos na medida em que estão incluídos ou fazem parte das relações de poder). Segundo Bourdieu (2002, p. 224-225):

[...] o conteúdo prático da lei que se revela no veredicto é o resultado de uma luta simbólica entre profissionais dotados de poder, portanto, capazes de mobilizar, embora de modo desigual, os meios ou recursos jurídicos disponíveis, pela exploração das "regras possíveis", e de os utilizar eficazmente, quer dizer, como armas simbólicas, para fazer triunfar a sua causa; o efeito jurídico da regra, quer dizer, a sua significação real, determina-se na relação de força específica entre os profissionais, podendo-se pensar que essa relação tende a corresponder (tudo o mais sendo igual do ponto de vista do valor na equidade pura das causas em questão) à relação de força entre os que estão sujeitos à jurisdição respectiva [grifo nosso].

A força simbólica da forma de apresentação das codificações consagram as competências técnicas dos agentes do Poder Judiciário como superior. Serve como fator de hierarquização entre os atores sociais, colocando os agentes do poder em situação favorável na relação aos demais atores (sujeitos).

Quanto ao funcionamento dos aparatos judiciários, notamos que os feitos delituosos cometidos pelos indivíduos no distrito judiciário de Campo Mourão estavam sob a jurisdição de um Magistrado que atuava a uma distância de aproximadamente 200 quilômetros. Nos autos 2/49 às folhas 14, por exemplo, observamos um mandado de 17 de abril de 1930, intimando algumas testemunhas residentes no distrito para comparecerem à Sala do Fórum em Guarapuava no dia " 21 do mês corrente às 13 horas, a fim de deporem no processo crime a que responde o réu [...]". Isto é, um deslocamento de local consideravelmente longo se pensarmos nas condições de transporte dos anos 1930 (nos autos referentes à caixa de número 1, notamos que o principal meio de locomoção era o cavalo e a carroça). Acreditamos que esta distância dos aparatos em relação ao seu locus de atuação dificultava a ação dos agentes quanto ao controle das ações e omissões dos indivíduos.

Neste ínterim, quanto ao movimento de controle do espaço e suas alocações, frente às mudanças políticas e constitucionais do país (entre elas, a outorga de uma nova constituição e o advento do Estado Novo), houve uma importante alteração no decorrer dos anos seguintes

13 "É justamente a regra que permite que seja feita violência à violência e que uma outra dominação possa dobrar aqueles que dominam. Em si mesmas, as regras são vazias, violentas, não finalizadas; elas são feitas para servir a isto ou àquilo; elas podem ser burladas ao sabor da vontade de uns e de outros" (FOUCAULT, 2015, p. 69). 
quanto ao "método da exclusão" na consideração do domínio particular das terras reconhecendo a propriedade rural ou urbana com domicílio por, pelo menos, 10 anos contínuos, sem oposição de reconhecimento de domínio alheio e que fosse produtiva, como "excluída" da possibilidade de tornar-se terra devoluta, por meio de sentença declaratória ${ }^{14}$ nos termos do art. 148 da Constituição Federal, de 10 de novembro de $1937 .{ }^{15}$ Esta nova política de domínio da propriedade, nos indica a presença de um novo arranjo espacial para o território (que incluía mais atores) para a dinâmica de distribuição, ensejando a necessidade de nova dinâmica nas políticas estratégicas de marcação, delimitação e estabelecimento dos lugares e, também, do controle dos indivíduos.

As políticas de medição e demarcação do perímetro urbano do distrito de Campo Mourão se dão em meio a essas mudanças político/jurídicas e, frente aos diversos interesses e necessidades dos atores sociais, estas não acontecem de forma tranquila e inquestionável, havendo, de acordo com Onofre (2005, p. 62), "polêmicas"16 quanto às suas execuções:

\begin{abstract}
A localização definitiva do perímetro urbano de Campo Mourão levantou polêmicas entre os moradores, sendo necessária, no ano de 1939, a demarcação da área de 2.000 hectares pelo Departamento de Geografia, Terra e Colonização D.G.T.C., dirigido pelo engenheiro Sady Silva, juntamente com a colaboração de João Lemos do Prado [grifo nosso].
\end{abstract}

O processo de demarcação das terras, segundo o Caderno de número 1 da Coletânea de Legislação e Estudos Terra e Cidadania do ITCG (2008, p. 14) não se revestiam das formalidades e requisitos indispensáveis a uma discriminação segura:

A ausência de uma legislação atual e consentânea com a nova realidade imobilizava a Administração Pública em sua atividade definidora e ordenadora do meio rural. A aquisição de terras devolutas já não obedecia a processo regular de colonização. Não era mais ao Poder Executivo que o particular recorria; o instrumento de regularização das terras devolutas passou a ser a ação de usucapião [grifo nosso].

Observamos, desse modo, que havia problemas na definição e ordenação das propriedades na gestão dos agentes do Estado.

14 Sentença que declara a existência ou inexistência de uma relação jurídica.

15 Art. 148 - Todo o brasileiro que não sendo proprietário rural ou urbano, ocupar por 10 anos contínuos, sem oposição nem reconhecimento de domínio alheio, um trecho de terra de até 10 hectares, tornando-o produtivo com o seu trabalho e tendo nele a sua morada, adquirirá o domínio mediante sentença declaratória, devidam ente transcrita.

16 Quanto às "polêmicas", em conversa com o Sr. Adailton (funcionário do Fórum de Campo Mourão e antigo morador de Campo Mourão) este nos apresentou uma possível controvérsia quanto ao estabelecimento do lugar para a praça da cidade (Praça Getúlio Vargas). Adailton disse que o lugar escolhido primeiramente seria onde hoje está instalada uma grande indústria (JBS) em Campo Mourão e que por "questões políticas" este lugar foi mudado. Também, em entrevista com Eduardo Moreira da Luz (meu avô) este relatou que houve grandes expectativas, na época, de que a primeira praça seria ou onde hoje é o Jardim Santa Cruz ou, talvez, onde hoje é o Lar Paraná. De qualquer modo, observamos nos documentos referentes ao tema que houve divergências de interesses quanto às medições, demarcações e estabelecimento do perímetro urbano da cidade. 
Em meio a estes problemas, alguns moradores, também, promoveram suas próprias ações para a proteção e/ou apropriação do espaço que ocupavam ou queriam ocupar. Nos autos de ação criminal 43/56, arquivado em 21/12/1956, ${ }^{17}$ observamos, nas palavras do advogado Dr. Ramonn, ${ }^{18}$ a seguinte justificativa quanto à resistência e ao "espírito de posse" de alguns dos moradores:

Dada a palavra ao Dr. Ramonn por este foi dito que: José Bezerra é filho de Michel Bezerra, este, um dos pioneiros e fundadores do primitivo núcleo de Campo Mourão, tendo passado a residir nestas plagas em 1.907, juntamente com os outros irmãos Bezerra [...] Fazer roçadas extensivas todos os anos, incendiando e destruindo matas para abrir pastagens naturais, foi trabalho realizado perenemente pelos irmãos Bezerra, pelos Moreira e pelos Dicró. Aí estão hoje os imensos samambaiais e carrascais, como fidedignas testemunhas. Era a amplidão e largueza, era a despreocupação com divisas e limites. As imensas Glebas pareciam eternas e os direitos ${ }^{19}$ de posse dos moradores não encontravam marcos, estacas, piquetes ou picadas. Desde a campina do Vitorino, hoje Campina da Lagoa, desde o Mamburê até as margens do Corumbataí e Ivaí; desde o Goio Erê até Tuneiras e outros locais, por toda a parte caminhavam os Bezerra, roçando, queimando, caçando. Assim se formou em seus espíritos aquela concepção de que tudo isto lhes pertencia por direito de posse - a posse indiscriminada, sem limites, sem fronteiras, sem disciplinas, sem divisas [grifo nosso].

Observamos no discurso do advogado o emprego do argumento de um "espírito" avesso aos marcos, estacas, limites, fronteiras e disciplinas, justificado pela chegada anterior ao local e pelo trabalho desempenhado neste. De certa forma, a aproximação dos aparatos de controle não significa, por si só, a disciplinação das condutas (como, talvez, pudéssemos imaginar).

Dr. Ramonn descreve, também, em seu discurso, a intervenção dos agentes do Estado nos estabelecimentos de divisas e demarcações, e relata a resistência de alguns moradores quanto às sanções normalizadoras referentes à limitação do espaço e à disciplina dos sujeitos:

\begin{abstract}
Mas após muitos e muitos anos de tramitação pelas repartições competentes, o verdadeiro direito de posse - a posse coletiva de 1.893, realizada de acordo com as disposições do Decreto $n^{\circ} 1$, de 8 de abril de 1893, o verdadeiro direito de posse havia de ser legitimado, estabelecendo-se divisas perimétricas do "Registro de Campo Mourão". Com a medição veio a divisão realizada por autoridades do Departamento de Terras, Geografia e colonização. Foram feitos os levantamentos e constatações de moradores e posseiros na Gleba, já então denominada "Gleba Registro de Campo Mourão". Foram disciplinadas as posses, áreas e benfeitorias. Distinguiram-se e se esclareceram os direitos de uns e de outros. José Bezerra também foi beneficiado com a medição, constatação e divisão da Gleba. Nunca contestou ou opôs embargos aos trabalhos, que acompanhou com seus filhos e
\end{abstract}

17 Trouxemos para a análise estes autos que, apesar de terem sido arquivados num período posterior ao analisado agora (1956), relatam fatos relativos ao período de análise desta seção.

18 Dr. Rammon, irmãos Bezerra, os "Moreira" e os Dicró são nomes fictícios. No decorrer desta pesquisa, alguns dos nomes nos autos serão trocados no sentido ético de preservar identidades.

19 Palavra sublinhada no processo-crime. 
genros, também posseiros e ocupantes de áreas, todos que, de agregados passaram a ser proprietários. Mas ficara-Ihe no espírito aquela liberalidade de antes - roçar, plantar, criar, queimar, caçar por toda parte. Não Ihes era concebível a limitação e disciplina. O seu ânimo era e é o de persistir na largueza absoluta de outrora e de sempre. Entretanto, lá está o seu lote, devidamente demarcado, com posse constatada, com marcos, estacas, picadas, número, área certa e o protocolo de requerimento [grifo nosso].

Diante das necessidades de medição/demarcação e das resistências e "polêmicas" entre os moradores em relação à ocupação deste espaço, foi realizado o pedido de revogação do título de n 000013 por parte do Município de Guarapuava. E, em 1943, sob o Decreto n 199, o distrito de Campo Mourão perde parte de sua extensão para o território de Iguaçu passando a pertencer ao novo município de Pitanga (FERREIRA, 1999). Passou-se então o distrito de Campo Mourão à jurisdição da comarca de Pitanga (1944-1947).

Neste período, encontramos sete feitos criminais, num espaço territorial significativamente menor (sem o espaço referente ao município de Guarapuava e sem o território de lguaçu), referentes aos delitos de lesão corporal, crime contra o patrimônio do Estado (queimada em roça), tentativa de homicídio, crime de sedução e homicídio doloso (em um dos casos por conflitos sobre um "território de roça") todos tipificados, desta vez, por uma nova codificação penal - Código Penal (Decreto-Lei n².848, de 7 de dezembro de 1940), o Código de Processo Penal (Decreto-Lei $n^{\circ} 3.688$, de 3 de outubro de 1941) e a Lei de Contravenções Penais (Decreto-Lei $n^{\circ}$ 3.689, de 3 de outubro de 1942) codificação que continua até o tempo presente, salvo ligeiras modificações.

Tabela 2 - Processos sob a jurisdição da Comarca de Pitanga (1944 -1947)

\begin{tabular}{ccccc} 
Comarca & Data & Local & Crime & Autos \\
\hline Pitanga & $08 / 04 / 1944$ & Estiva & Lesões corporais com cabos de "mango" e relho & $13 / 49$ \\
\hline Pitanga & $01 / 08 / 1945$ & Rio Formoso & $\begin{array}{c}\text { Acusado ateou fogo em uma área de 38 alqueires de } \\
\text { terras devolutas do domínio do Estado }\end{array}$ & $12 / 49$ \\
\hline Pitanga & $01 / 08 / 1945$ & Cruzinha & Tentativa de homicídio & $6 / 49$ \\
\hline Pitanga & $02 / 09 / 1945$ & C. Mourão & Lesão corporal em baile por discussão & $9 / 49$ \\
\hline Pitanga & $02 / 10 / 1945$ & Tateto & Crime de Sedução & $11 / 47$ \\
\hline Pitanga & $01 / 09 / 1946$ & Trinta e Nove & Homicídio - luta com faca & $7 / 49$ \\
\hline Pitanga & $01 / 09 / 1946$ & Pensamento & Lesões corporais - luta com facão & $10 / 49$ \\
\hline
\end{tabular}

Fonte: Arquivo da Primeira Vara Criminal de Campo Mourão-PR

Vemos que, num período e num espaço menor que o anterior, o número de delitos alcançados pelos aparatos de poder judiciário mais do que dobra.

Mesmo que, por um momento, possamos cogitar que os arquivos consultados tenham deixado de recolher papéis, entretanto é razoável aceitar que o Estado moderno, precisando registrar e escrever os acontecimentos delituosos para mais bem controlálos, acaba aumentando o número de delitos em função de seus registros e 
assinalações (este é um processo típico que caracterizou o advento do Estado moderno consentâneo à difusão e disseminação de uma cultura do escrito): voltamos nossa atenção para um período histórico - décadas 1940-1960 - em que a sociedade brasileira vivenciou um intenso processo de urbanização, industrialização, modernização, mudanças de valores culturais e de grande efervescência de projetos políticos que resultaram na implantação de uma nova ordem jurídico-penal para administrar as situações de litigiosidade e o desenrolar das relações entre os indivíduos e os grupos sociais (ROLIM, 2007, p. 99).

Entretanto, apesar deste esforço para uma maior aproximação dos aparatos judiciários do Estado e do maior número de feitos delituosos alcançados, o distrito de Campo Mourão não permanece muito tempo sob o domínio do município de Pitanga, o que nos sugere a necessidade/interesse político/jurídico maior de focalização/aproximação ao locus onde os agentes estavam distribuídos para melhor controlá-los.

Em meio a estes possíveis interesses/necessidades, em outubro de 1947 foi emancipado o município de Campo Mourão.

Figura 2 - Organograma de dependência genealógica

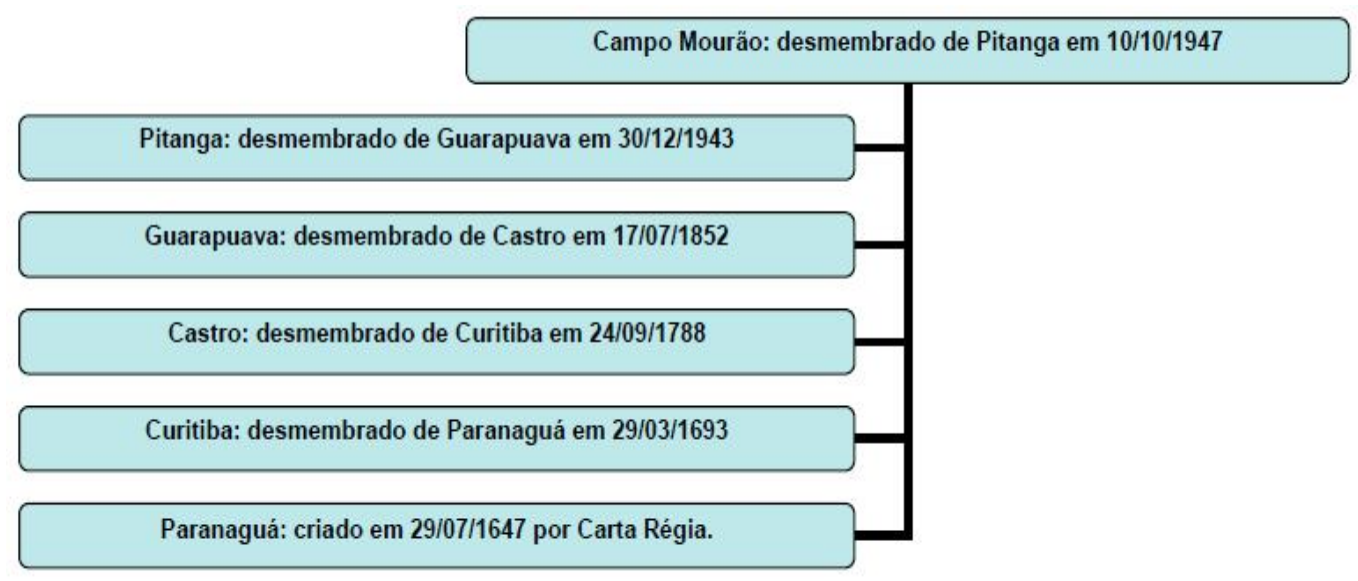

Fonte: Silva (2008).

Notamos o caminho para a emancipação no organograma acima, com os desmembramentos políticos e um movimento de redução geográfica desde a criação de Paranaguá até a emancipação do município de Campo Mourão.

Silva (2008, p. 33) narra que os fatores que levaram a emancipação foram o aumento populacional e a diligência política dos moradores junto ao governador Lupion:20 
Em consequência do aumento populacional, paralelamente a fatores políticos, como por exemplo, a vitória do governador Lupion, no qual votaram maciçamente vários moradores mourãoenses e o empenho de Francisco Albuquerque junto ao governador, finalmente, em 10 de outubro de 1947, Campo Mourão emancipa-se de Pitanga [...], sendo elevado à categoria de município pela Lei $\mathrm{n}^{\circ} .2$ [grifo nosso].

Brasileiro (1973, p. 18) sinaliza como fator positivo ao movimento das "emancipações" a questão das necessidades das zonas rurais quanto à maior atenção das suas sedes urbanas:

O governo municipal que deveria atender tanto as necessidades das zonas urbanas sob sua jurisdição quanto às das rurais, tem tendido a restringir sua ação à sede do município, fazendo com que os distritos pressionem por sua emancipação almejando atrair mais recursos e mais atenção das esferas superiores do governo.

Ou seja, a diligência dos moradores, provavelmente, tinha como intuito uma "maior" independência administrativa no sentido de atrair mais recursos e atenção das esferas superiores de governo. A partir destas constatações, inferimos que os interesses dos agentes em emancipar o município estavam relacionados à necessidade de maior autonomia política e disponibilidade de recursos para a gestão desta "autonomia". Veremos no próximo item os meandros da instalação dos aparatos judiciários de controle e regulação da vida pública diante da emancipação do município de Campo Mourão.

\section{A Instalação dos Aparatos de Poder Judiciário}

Desde a publicação da lei que incorporava "Campo do Mourão" ao patrimônio da Câmara Municipal de Guarapuava em 1916, houve um esforço dos agentes do Estado em classificar, controlar e regulamentar o local caracterizando-o em patrimônio/vila1, distrito policial/judicial (1920) e depois em município e comarca (1947). Na análise dos primeiros autos de Campo Mourão, notamos a presença de estratégias de controle baseada em disposições, manobras, técnicas e funcionamentos a partir de classificação e categorização dos espaços onde os indivíduos estavam ou poderiam estar distribuídos. Estas estratégias de controle do espaço esbarraram na ausência de uma legislação atual e consentânea com a nova realidade, segundo o ITCQ (2008), e, também, nas divergências de interesses/necessidades de alguns dos moradores quanto à distribuição/alocação dos lugares.

O processo 14/49, arquivado em 10/04/1952, traz um caso em particular que demonstra sérias tensões na disputa pelo espaço em Campo Mourão:

No dia 26 de março p. passado, em Barreiro do Oeste, às 15 horas mais ou menos o denunciado AMBRÓSIO LIRA, após ter discutido acaloradamente com ZULMIRA TRIGUEIRO e PEDRO CARDOSO, por motivo de uma questão de roça, desfechou contra a primeira um tiro de espingarda, matando-a quase instantaneamente, conforme auto de exame cadavérico de fls.; em seguida, na sua fúria assassina, 
perseguiu PEDRO CARDOSO que, alarmado, entrou em sua residência. $O$ homicida lá penetrou também e detonou a arma duas vezes contra PEDRO CARDOSO, prostrando-o sem vida, conforme auto de exame cadavérico de fls.; Insatisfeito o bárbaro matador carregou novamente a arma afim de tirar a vida da companheira de PEDRO, pois ao seu lado se encontrava. Ameaçada por AMBRÓSIO LIRA, percebendo o perigo iminente, a jovem MARIA APARECIDA FIGUEIREDO fugiu espavorida para o mato, enquanto aquele homicida lhe despejava dois tiros de espingarda, um dos quais a atingiu no ombro, conforme consta no auto de exame de corpo de delito de fls. 2 (AUTOS 11/49, fls. 2).

No auto de interrogatório às folhas $25 / 26$ dos autos, o réu declara para o inspetor policial o motivo (provável) da desavença:

[...] o administrador da Colônia Mamburê havia fornecido ao interrogado uma licença para que o mesmo plantasse no tiguera e no mato; que apesar disso as vítimas não fizeram caso da determinação da autoridade, dizendo que a licença deles tinha mais valor que a do interrogado por ser mais antiga; que finalmente no dia vinte e quatro de março deste ano o interrogado dirigiu-se a Mamburê a procura do senhor Otávio, administrador da Colônia, que Ihe prometeu expulsar as vítimas da roça do interrogado [...] [grifo nosso].

Este desacordo sobre a apropriação das terras demonstra a maneira como alguns moradores lidavam com a acumulação dos bens (território) e com o estatuto jurídico da propriedade.

Foucault (1987, p. 80), observa esta relação em Vigiar e Punir em um movimento que "vai de uma sociedade da apropriação jurídico-política a uma sociedade da apropriação dos meios e produtos do trabalho". Esta "nova" fórmula ("legalizada") para os moradores acumularem, os "novos" estatutos jurídicos concernentes a ela e a relação destas com os atores sociais e suas experiências, demandou maior aproximação/focalização dos aparatos de controle judiciários no locus. Neste contexto, em conjunto ao movimento de emancipação da cidade ocorre o movimento de criação da comarca de Campo Mourão.

Quanto aos meandros da criação da comarca, numa das primeiras disposições jurídicas nacionais a respeito da criação de comarcas, especificamente no artigo $3^{\circ}$ do Código do Processo Criminal de Primeira Instancia (Lei de 29 de novembro de 1832) observamos a seguinte disposição:

Na Provincia, onde estiver a Côrte, o Governo, e nas outras os Presidentes em Conselho, farão quanto antes a nova divisão de Termos, e Comarcas proporcionada, quanto fôr possivel, á concentração, dispersão, e necessidade dos habitantes, pondo logo em execução essa divisão, e participando ao Corpo Legislativo para ultima approvação. $^{21}$ 
Vemos, neste momento histórico, que havia urgência nos atos de divisão e execução: "farão quanto antes a nova divisão [...] pondo logo a execução" na normativa nacional, o que nos sugere uma predisposição, neste momento, das esferas superiores do governo para a criação de novas comarcas.

No entanto, a Constituição de 1937 aboliu o princípio da autonomia municipal centralizando o poder na União. A razão para esta política era a "proposição do Estado Novo de desmontar a máquina da República Velha, sustentada pelas oligarquias, cujo reduto estava nos municípios" (CIGOLINI, 1999, p. 16) o que, por sua vez, pode ter adiado em alguns anos a criação dos municípios e das comarcas de Pitanga e de Campo Mourão.

Após 1945, diante do novo momento político nacional (fim do primeiro governo de Getúlio Vargas e nova constituinte em 1946) e da "onda emancipacionista" no Brasil ocorre, novamente, um movimento positivo favorável à criação das novas comarcas. No entanto, os critérios para as criações das comarcas não eram explicitados e nem discutidos, pois não havia regras claras sobre a criação das comarcas (NEQUETE, 2000). Deste modo, quanto aos meandros da criação da comarca de Campo Mourão, acreditamos que se poderia prevalecer o subjetivismo do legislador e do administrador judicial, que poderiam perseguir o interesse coletivo ou mesmo o seu interesse pessoal.

Os primeiros processos criminais desta "nova" comarca demonstram as seguintes informações:

Tabela 3 - Processos sob a jurisdição da Comarca de Campo Mourão (1944 -1946).

\begin{tabular}{lcccc} 
Comarca & Data & Local & Crime & Autos \\
\hline Campo Mourão & $04 / 11 / 1947$ & Araruna & $\begin{array}{c}\text { Lesões corporais em acerto de contas por } \\
\text { trabalho }\end{array}$ & $05 / 49$ \\
\hline Campo Mourão & $11 / 04 / 1949$ & "Mamburê" & $\begin{array}{c}\text { Homicídios e lesão corporal - Conflito por } \\
\text { causa de propriedade de roça }\end{array}$ & $14 / 49$ \\
\hline Campo Mourão & $20 / 04 / 1949$ & Barreiro & Homicídios - com facão & $16 / 49$ \\
\hline Campo Mourão & $27 / 05 / 1949$ & $\begin{array}{c}\text { Campina do } \\
\text { Amoral }\end{array}$ & $\begin{array}{c}\text { Lesões corporais - briga por causa de } \\
\text { corrida de cavalo }\end{array}$ & $19 / 49$ \\
\hline Campo Mourão & $27 / 05 / 1949$ & Rio da Areia & Homicídio - em baile & $20 / 49$ \\
\hline Campo Mourão & $11 / 06 / 1949$ & Peabiru & Tentativa de homicídio & $18 / 49$ \\
\hline Campo Mourão & $11 / 06 / 1949$ & Peabiru & Homicídio & $17 / 49$ \\
\hline Campo Mourão & s/data & $\begin{array}{c}\text { Campo } \\
\text { Mourão }\end{array}$ & Desacato ao Juiz & $8 / 49$
\end{tabular}

Fonte: Arquivo da Primeira Vara Criminal de Campo Mourão-PR

No período de aproximadamente dois anos (1947-1949) encontramos oito feitos, num espaço territorial menor que o da comarca anterior (sem o espaço relativo ao município de Pitanga), referentes aos delitos de lesão corporal, homicídio, tentativa de homicídio e 
desacato, nos lugares denominados: Araruna, "Mamburê", Barreiro, Campina do Amoral, Rio da Areia, Peabiru e Campo Mourão. É a prática jurídica atuando, deste modo, sobre a dinâmica social ao criminalizar condutas e comportamentos por intermédio das codificações normativas contidas na engenharia disciplinar vigente (ASSIER-ANDRIEU, 2000). O Gráfico 1 apresenta o aumento percentual dos feitos nas diferentes comarcas a que Campo Mourão ficou jurisdicionado.

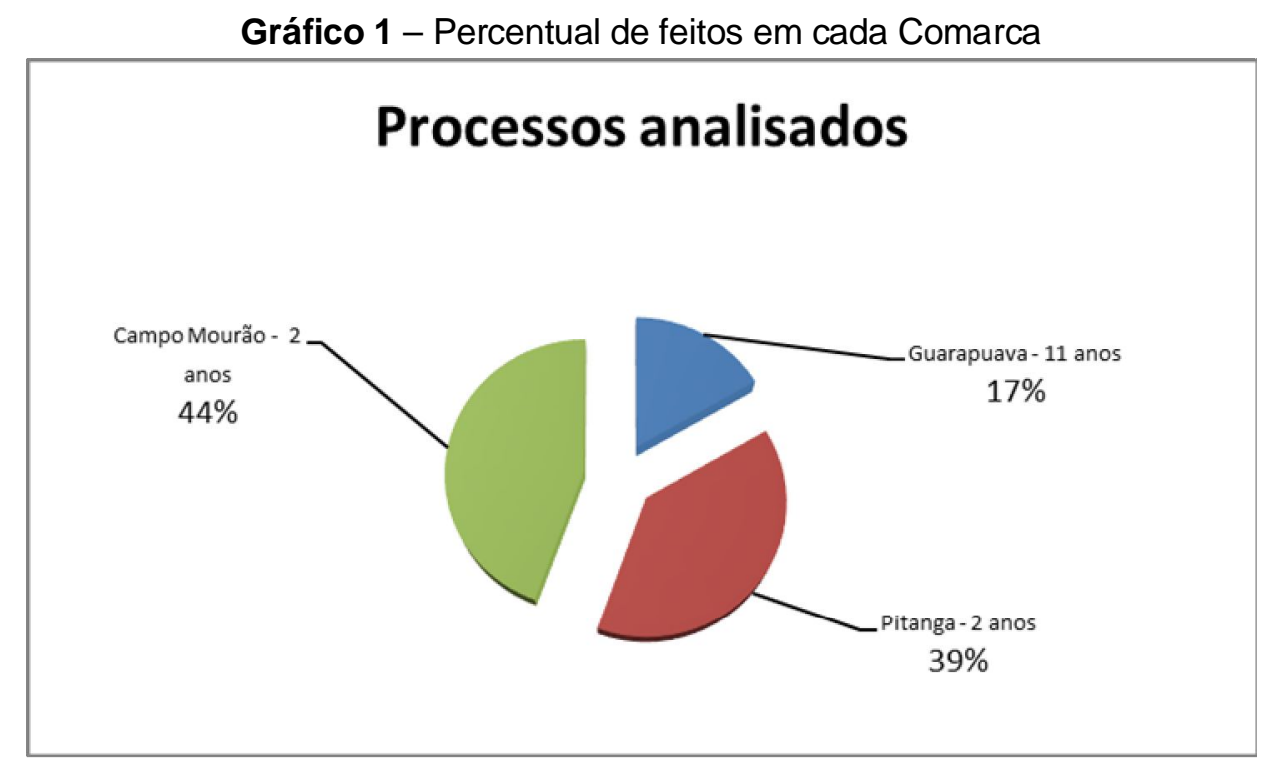

Fonte: Organização do autor.

Os feitos delituosos alcançados pelos aparatos de poder judiciário no distrito de Campo Mourão sob jurisdição da comarca de Guarapuava, durante os anos de 1928-1939 (onze anos), representam 17\% do total dos processos-crime da caixa de arquivo de número 1.

Em apenas dois anos como comarca de Pitanga os processos relativos a esta comarca representam $39 \%$, ou seja, mais que o dobro em um período substantivamente menor (2 anos). Este percentual de feitos delitivos alcançados pelos aparatos aumenta nos dois anos analisados em que o território tem jurisdição própria: 44\%. Numa análise geral dos feitos das três comarcas, observamos um aumento percentual significativo na quantidade dos conflitos alcançados pelos aparatos judiciários, o que, por sua vez, nos sugere mudanças nas condições de concentração e dispersão dos habitantes e, também, na relação de "maior/menor controle" e sistematização/organização da vida social em Campo Mourão.

Por fim, este "caminho" para a emancipação da cidade e criação da comarca traçado por meio das disposições normativas e aproximações dos aparatos jurídicos do Estado, seja por uma política, aparentemente racionalista, de propriedades das terras ou pela instalação 
dos aparatos jurídicos de poder, nos demonstra que houve um movimento de aproximação, focalização e instalação a partir de uma política de regulação, disciplinação e controle, dispostos ao locus de interação dos atores inseridos num cenário e contexto inicial da ocupação do território de Campo Mourão.

\section{Considerações Finais}

Ao entrever os meandros do processo de emancipação do município e a criação da comarca de Campo Mourão através da análise dos fatos relacionados às positivações político/jurídicas, medição e demarcação do espaço, necessidade de gestão e controle dos indivíduos pelos agentes do Estado e dos primeiros processos-crime arquivados, observamos como cenário um locus (considerado pelos agentes do Estado como uma "terra sem donos") que demonstrava tensões e polêmicas no decorrer de sua apropriação pelos atores sociais, num contexto de tentativas de implementação de políticas de controle e alocação dos espaços. Estas políticas aparentemente racionalistas podem ser observadas através das classificações e estabelecimentos frente a concentração e/ou dispersão (e seus desdobramentos) dos habitantes quanto ao território e, também, quanto a si próprios em ações de inclusão e exclusão mais ou menos administradas pelos agentes do Estado.

Classificaram o território de Campo Mourão em patrimônio, vila, distrito, município, cidade, comarca etc. O que, por sua vez, no remeteu ao caminho Guarapuava/Pitanga/Campo Mourão como a base do processo inicial de ocupação, organizada pelos agentes do Estado, da cidade de entre 1916 (incorporação do patrimônio à Guarapuava) e 1947 (emancipação do município). Num movimento centrípeto (quanto à concentração dos habitantes) com diminuição do território, motivado pelos interesses e necessidades dos indivíduos quanto ao estabelecimento dos lugares, apropriação dos recursos, maior atenção das esferas superiores de governo e ao interesse/necessidade de maior controle e disciplinação dos indivíduos.

Quanto ao controle dos atores sociais, o trinômio classificação/controle/regulação aparece a partir da necessidade/interesse da instalação de um aparato judiciário de controle num movimento, também, centrípeto quanto à aproximação das instituições do Estado ao locus onde ocorrem as ações/omissões dos agentes sociais, revelado aqui pelo mesmo caminho Guarapuava/Pitanga/Campo Mourão. O esforço de controle dos sujeitos se fez em meio a uma experiência local nova (escrita e legalizada) nas formas de acumulação e de estatuto jurídico da propriedade, ao qual alguns atores resistiram por meio de conflitos e confrontos. 
Desse modo, como observado na análise da caixa de arquivo de $\mathrm{n}^{\circ} 1$ da primeira vara criminal de Campo Mourão, houve um aumento percentual significativo na quantidade dos conflitos alcançados pelo aparato judiciário, o que, por sua vez, induz-nos a pensar em prováveis mudanças nas condições de concentração e dispersão dos habitantes e, também, na relação de "maior/menor controle" e sistematização/organização da vida social.

Sumariando, o ajuste de foco nos primórdios do território referente à Campo Mourão e em seu processo inicial de ocupação, nos trouxe como cenário um locus em vias de apropriação legal pelos atores sociais num contexto de tensões inexoráveis entre os sujeitos na classificação/controle/regulação dos locais. Situação conflituosa para cuja análise o ferramental foucaultiano de exercício de poder pela repressão/exclusão, mas também pela autorização/inclusão, pode bem servir de aporte para verificar como a configuração do Estado moderno em Campo Mourão (um pequeno locus disperso nesse universo territorial interior do Paraná) assemelha-se a processos vividos em vários outros territórios em suas épocas de trânsito de sociedades tradicionais para sociedades modernas na constituição da modernidade ocidental.

\section{Referências}

ALVAREZ, Marcos César. Michel Foucault e a Sociologia: aproximações e tensões. Estudos de Sociologia, Araraquara, v. 20, n. 38, p. 15-33, 2015.

ASSIER-ANDRIEU, Louis. O direito nas sociedades humanas. São Paulo: Martins Fontes, 2000.

BLIKSTEIN, Izidoro. Kaspar Hauser ou A Fabricação da Realidade. 4. ed. São Paulo: Cultrix, 1995.

BOURDIEU, Pierre. O poder simbólico. Rio de Janeiro: Bertrand Brasil, 2002. (Coleção Memória e Sociedade).

BRASIL. Constituição (1891). Constituição da República dos Estados Unidos do Brasil. Rio de Janeiro, 24 de fevereiro de 1891. Disponível em: http://www.planalto.gov.br/ccivil_03/constituicao/constituicao91.htm. Acesso em: 18 set. 2016.

BRASIL. Constituição (1937). Constituição da República dos Estados Unidos do Brasil. Rio de Janeiro, 10 de novembro de 1937. Disponível em: http://www.planalto.gov.br/ccivil_03/constituicao/constituica037.htm. Acesso em: 21 ago. 2016.

BRASIL. Decreto-lei n. 2.848, de 7 de dezembro de 1940. Código Penal. Rio de Janeiro, 1940. Disponível em: http://www.planalto.gov.br/ccivil_03/decreto-lei/Del2848.htm. Acesso em: 21 ago. 2016.

BRASIL. Decreto-lei n. 3.688, de 3 de outubro de 1941. Lei das Contravenções Penais. Rio de Janeiro, 1941. Disponível em: http://www.planalto.gov.br/ccivil_03/decreto-lei/Del3688.htm. Acesso em: 24 ago. 2016. 
BRASIL. Decreto-lei n. 3.689, de 3 de outubro de 1941. Código de Processo Penal. Rio de Janeiro, 1941. Disponível em: http://www.planalto.gov.br/ccivil_03/decreto-lei/Del3689.htm. Acesso em: 21 ago. 2016.

BRASIL. Lei de 29 de novembro de 1832. Promulga o Codigo do Processo Criminal de primeira instancia com disposição provisoria ácerca da administração da Justiça Civil. Rio de Janeiro, 1832. Disponível em: http://www.planalto.gov.br/ccivil_03/leis/LIM/LIM-29-111832.htm. Acesso em: 23 ago. 2016.

BRASIL. Lei n. 3.071, de $1^{\circ}$ de janeiro de 1916. Código Civil. Rio de Janeiro, 1916. Disponível em: http://www.planalto.gov.br/ccivil_03/leis/L3071.htm. Acesso em: 18 set. 2016.

BRASILEIRO, Ana Maria. O município como sistema político. Rio de Janeiro: Fundação Getúlio Vargas, 1973.

CAMPO Mourão. Folha de Londrina, Londrina, 10 out. 1976. Edição especial.

CAMPO MOURÃO. Museu Municipal Deolindo Mendes Pereira. Campo Mourão, 2017.

CASA CIVIL. Lei n. 2, de 11 de outubro de 1947. Sistema Estadual de Legislação. Disponível em:

http://www.legislacao.pr.gov.br/legislacao/listarAtosAno.do?action=exibir\&codAto=15788\&indic $\mathrm{e}=1$ \&totalRegistros=24\&anoSpan=1947\&anoSelecionado=1947\&mesSelecionado=0\&isPagin ado=true. Acesso em: 14 abr. 2016.

CASA CIVIL. Lei n. 315, de 19 de dezembro de 1949. Livro Primeiro da Administração da Justiça.

Disponível

em:

http://www.legislacao.pr.gov.br/legislacao/listarAtosAno.do?action=exibir\&codAto=16234\&indic $\mathrm{e}=1$ \&totalRegistros $=154 \&$ anoSpan $=1$ 956\&anoSelecionado=1949\&mesSelecionado=0\&isPagi nado=true. Acesso em: 23 ago. 2016.

CHALHOUB, Sidney. Trabalho, lar e botequim: o cotidiano dos trabalhadores no Rio de Janeiro da belle époque. 3. ed. Campinas: Editora da Unicamp, 2012.

CIGOLINI, Adilar Antonio. A fragmentação do território em unidades político-administrativas: análise da criação de municípios no Estado do Paraná. 1999. 141 f. Dissertação (Mestrado em Geografia) - Universidade Federal de Santa Catarina, Florianópolis, 1999.

DI PIETRO, Maria Sylvia Zanella. Direito Administrativo. 15. ed. São Paulo: Atlas, 2003.

FAUSTO, Boris. Crime e cotidiano: a criminalidade em São Paulo, 1880-1924. São Paulo: Edusp, 1984.

FERREIRA, João Carlos Vicente. O Paraná e seus municípios. 3. ed. [S. I.]: Memória do Brasil, 1999.

FISCHER, Rosa Maria Bueno. Foucault e a análise do discurso em educação. Cadernos de Pesquisa, São Paulo, n. 114, p. 197-223, nov. 2001.

FLICK, Uwe. Introdução à Pesquisa Qualitativa. Madri: Ediciones Morata, 2007.

FONTANELLA, Bruno José Barcellos; RICAS, Janete; TURATO, Egberto Ribeiro. Amostragem por saturação em pesquisas qualitativas. Cadernos de Saúde Pública, Rio de Janeiro, v. 24, n. 1, p. 17-27, 2008. 
FOUCAULT, Michel. Microfísica do poder. Rio de Janeiro: Graal, 2015.

FOUCAULT, Michel. Outros espaços. In: MOTTA, Manoel Barros da (org.). Estética: literatura e pintura, música e cinema. Rio de Janeiro: Forense Universitária, 2001. p. 411-422. (Ditos e Escritos, 3).

FOUCAULT, Michel. Vigiar e Punir. Petrópolis: Vozes, 1987.

GIL, Antônio Carlos. Como elaborar projetos de pesquisa. 3. ed. São Paulo: Atlas, 1991.

GODET, Michel. Prospective et planification stratégique. Paris: Economica, 1985.

IBGE - INSTITUTO BRASILEIRO DE GEOGRAFIA E ESTATÍSTICA. Campo Mourão. Rio de Janeiro: $\quad$ IBGE, [2007?]. Disponível em: http://biblioteca.ibge.gov.br/visualizacao/dtbs/parana/campomourao.pdf. Acesso em: 4 ago. 2016.

LATOUR, Bruno. Jamais fomos modernos: ensaio de antropologia simétrica. Rio de Janeiro: Ed. 34, 1994.

LEGISLAÇÃO de Campo Mourão. In: LIZ SERVIÇOS ONLINE LTDA. LeisMunicipais. Itapema, [2017]. Disponível em: https://leismunicipais.com.br/legislacao-municipal/3211/leisde-campo-mourao. Acesso em: 30 ago. 2017.

MACHADO, Roberto Cabral de Melo. A arqueologia do saber e a constituição das ciências humanas. Discurso, São Paulo, v. 5, n. 5, p. 87-118, 1974.

MORIN, Edgar. Epistemologia da Complexidade. In: SCHNITMAN, Dora Fried (org.). Novos paradigmas, cultura e subjetividade. Porto Alegre: Artes Médicas, 1996. p. 274-286.

NEQUETE, Lenine. O Poder Judiciário no Brasil a partir da independência. Brasília: STF, 2000.

ONOFRE, Gisele Ramos. Campo Mourão: colonização, uso do solo e impactos socioambientais. 2005. 206 f. Dissertação (Mestrado em Geografia) - Universidade Estadual de Maringá, Maringá, 2005.

PAUL, Patrick. Pensamento complexo e interdisciplinaridade: abertura para mudança de paradigma. In: PHILLIPI JR, Arlindo; SILVA NETO, Antonio J. (ed.). Interdisciplinaridade em Ciência, Tecnologia \& Inovação. Barueri: Editora Manole, 2011. p. 229-259.

RAGO, Margareth. Do cabaré ao lar. a utopia da cidade disciplinar. 4. ed. São Paulo: Paz e Terra, 2014.

RAMOS, Marília Patta. Métodos quantitativos e pesquisa em Ciências Sociais: lógica e utilidade do uso da quantificação nas explicações dos fenômenos sociais. Mediações: Revista de Ciências Sociais, Londrina, v. 18, n. 1, p. 55-65, jan./jun. 2013.

RIBEIRO, Carlos Antonio Costa. Cor e criminalidade: estudo e análise da justiça do Rio de Janeiro (1900-1930). Rio de Janeiro: Editora UFRJ, 1995.

RICHARDSON, Roberto Jarry. Pesquisa social: métodos e técnicas. 3. ed. São Paulo: Atlas, 1999. 
ROSEMBERG, André; SOUZA, Luís Antônio Francisco de. Notas sobre o uso de documentos judiciais como fonte de pesquisa histórica. Patrimônio e Memória, Assis, v. 5, n. 2, p. 159-173, 2009.

SILVA, Deonísio da. De onde vêm as palavras: origens e curiosidades da língua portuguesa. 17. ed. Rio de Janeiro: Lexicon, 2014.

SILVA, Ivanete Pereira Martins da. Dinâmica populacional e produção do espaço de Campo Mourão: a espaço temporalidade de um núcleo polarizador. 2008. 167 f. Dissertação (Mestrado em Geografia) - Universidade Estadual de Maringá, Maringá, 2008.

SOUZA, Luiz Antônio Francisco de. Poder de política, Política civil e práticas policiais na cidade de São Paulo (1889-1930). 1998. Tese (Doutorado em Sociologia) - Universidade de São Paulo, São Paulo, 1998.

TOURINO FILHO, Fernando da Costa. Manual de Processo Penal. São Paulo: Saraiva, 2005.

VASCONCELOS, Eduardo M. Complexidade e pesquisa interdisciplinar. Petrópolis: Vozes, 2007.

VEIGA, Pedro da. Campo Mourão: centro do progresso. Maringá: Bertoni, 1999.

WEBER, Max. A "objetividade" do conhecimento nas Ciências Sociais. São Paulo: Ática, 2006.

Recebido em 09/03/2018

Aprovado em 03/10/2018 